\title{
Työryhmästä toimikunta
}

Opetusministeriö asetti 25.2.1982 toimikunnan selvittämään jatkuvan koulutuksen periaatteiden toteuttamista koulutusjärjestelmässä ja sen kehittämistyössä. Toimikunta jatkaa aiemman työryhmän työn pohjalta.

Jatkuvan (elinikäisen) koulutuksen periaatteiden toteuttamiseen on viitattu muun muassa koulutusrakennekomitean (1969), vuoden 1971 koulutuskomitean, opetussuunnitelmakomitean ja aikuiskoulutuskomitean mietinnöissä.

Valtioneuvosto teki 7.6.1978 periaatepäätöksen aikuiskoulutuksen suunnittelu- ja kehittämisperiaatteista. Päätöksen mukaan koulutusjärjestelmää kehitetään jatkuvan koulutuksen periaatteen mukaisesti kokonaisuutena siten, että eri koulutusasteen ja -muodot kiinteästi niveltyvät toisiinsa ja että järjestelmällinen ja joustava opiskelu on mahdollista kaikkina ikäkausina.

Toimikunnan tehtävänä on:

1) selvittää, millaisia vaatimuksia jatkuvan koulutuksen periaate asettaa maamme koulutusjärjestelmälle pitäen erityisesti silmällä aikuiskoulutuksen kehittämistarpeita; sekä

2) selvittää, miten nämä vaatimukset tulee ottaa huomioon koulutussuunnittelussa.

Toimikunta voi työssään käyttää lähtökohtana opetusministeriön asettaman jatkuvan koulutuksen työryhmän suorittamaa jatkuvan koulutuksen määrittelyä ja sen määrittelemiä keskeisiä periaatteita sekä arviointiperusteita. Toimikunta joutuu suorittamaan arvioinnin jatkuvan koulutuksen periaatteiden toteutumisesta lähinnä aikuiskoulutusjärjestelmän piirissä ottaen huomioon sen yhteydet koulutusjärjestelmän muihin osiin.

Selvittelytyön jälkeen opetusministeriö ottaa kantaa selvityksien tuloksiin ja antaa ohjeet mahdollista jatkotyöskentelyä varten.

Kun toimikunnan työssä tulisi ottaa huomioon eri koulutusasteita koskeva kehittämistyö, ja siinä tulisi olla mukana opettajajärjestöjen ja tutkimuksen edustus siksi kokoonpano on seuraavaa:

Suunnittelupäällikkö Liekki Lehtisalo (opetusministeriö) puheenjohtajana

opetusneuvos Olavi Alkio (opetusministeriö)

korkeakouluneuvos Seppo Kiiskinen (opetusministeriö)

osastopäällikkö Aslak Lindström (Opettajien ammattijärjestö)

professori Matti Peltonen (Tampereen yliopisto)

filosofian toht. Singa Sandelin (Helsingin yliopisto)

professori Annika Takala (Joensuun korkeakoulu)

apulaisprofessori Tapio Vaherva (Jyväskylän yliopisto)

ylijohtaja Reijo Virtanen (ammattikasvatushallitus)

ylijohtaja Yrjö Yrjönsuuri (kouluhallitus).

Toimikunta joutuu selvittämään jatkuvan koulutuksen periaatteen toteuttamista, lähinnä aikuiskoulutuksen toiminnan järjestämisessä. Tehtävän laajuuden vuoksi toimikunnalle varataan vuoden pituinen työaika.

Tehtävien laajuuden vuoksi toimikunnalle otetaan päätoiminen sihteeri sekä kolme sivutoimista sihteeriä, jotka ovat hyvin perehtyneet eri koulutusasteita koskevaan kehittämistyöhön. Päätoimiseksi sihteeriksi on otettu VTM Sinikka Sorvari ja muiksi VTM Seppo Koistinen sekä suunnittelija Matti Poutanen. 